\title{
QUALITY
}

Volume 5, Nomor 1, 2017: 104-139

\section{MODEL PENDIDIKAN PEREDAM PEMIKIRAN DAN GERAKAN RADIKAL BELAJAR DARI KUDUS}

\author{
Moh Rosyid \\ STAIN Kudus \\ mrosyid72@yahoo.co.id
}

\begin{abstract}
Abstrak
Lembaga pendidikan yang menghasilkan generasi terdidik merupakan tempat diandalkan masyarakat tumbuhnya generasi berakhlakul karimah, ramah, santun, dan menaati peraturan negara dan agama. Akan tetapi, dalam realitanya, terdapat generasi yang terdidik tapi menjadi pelaku teroris. Hal ini terjadi karena kehidupannya berada di lingkungan (non-lembaga pendidikan) sangat mewarnai pola pikirnya. Dengan demikian, lingkungan sosial ikut besar andilnya dalam mencetak generasi yang radikal atau santun. Konsekuensi yang harus dilakukan oleh lembaga pendidikan formal dan nonformal adalah mengubah pola pembelajaran yang teks book menjadi pendidikan yang turun ke lapangan dengan muatan nilainilai toleransi intern dan antar-umat beragama. Perlu pula mewujudkan pendidikan Bela Negara yang sedang digarap oleh Kementerian Pertahanan RI era Presiden Jokowi-JK. Pendidikan toleran dan bela negara merupakan bagian dari upaya menangkal nalar radikal sehingga pendidik perlu melahirkan kiat pembelajaran yang tidak berkutat pada kelas dan teks, perlu pula menggagas pendidikan yang mengedepankan fakta riil sosial sebagai bahan telaah. Terjadinya nalar radikal karena hidup laksana katak dalam tempurung sehingga sesuatu yang berbeda diidentikkan dengan kesalahan. Perlunya antar-elemen sosial dan pemerintah menggugah kesadaran bahwa pendidikan sejati adalah pelaksanaan pendidikan di lingkungan rumah, lingkungan masyarakat, dan di lembaga pendidikan sebagai satu kesatuan, tidak hanya di lembaga pendidikan formal saja. Konsekuensinya, perlunya inovasi pembelajaran secara bersama dalam mewujudkan generasi yang terdidik dengan potensi cerdas dan berakhlak. Kiat pendidikan perlu mengedepankan pendidikan toleran agar menjadi generasi yang tidak fanatis dalam menghadapi perbedaan suku, agama, dan strata sosial di lingkungannya. Upaya ini diperkuat dengan fakta bahwa jaringan teroris telah menjadi wabah penyakit akut di negeri ini. Bahkan, pelaku teror mayoritas generasi yang terdidik, baik pendidikan formal maupun pendidikan keagamaan nonformal (keislaman).
\end{abstract}

Kata Kunci: pendidikan dan kesadaran menghadapi perbedaan

\footnotetext{
Abstract

Educational institutions that produce educated generation is a place of reliance on the growth of generations berakhlakul karimah, friendly, courteous, and obey the rules of the country and religion. However, in reality, there is an educated generation but a terrorist actor. This happens because his life is in the environment (non-
} 


\section{QUALITY}

Volume 5, Nomor 1, 2017: 104-139

educational institutions) are coloring his mindset. Thus, the social environment contributes to the creation of a radical or polite generation. The consequence that must be done by formal and non formal education institutions is to change the learning patterns that text book into education that comes to the field with the content of the values of internal tolerance and inter-religious people. It is also necessary to realize the education of Bela Negara which is being worked by the Ministry of Defense RI era Jokowi-JK President. Tolerant education and state defenses are part of the effort to counter radical reasoning so that educators need to produce learning tips that do not dwell on class and text, it is also necessary to create an education that puts forward the real facts of social as a matter of study. The occurrence of radical reasoning because life is like a frog in a shell so that something different is identified with error. The need for intergovernmental and social elements to raise awareness that true education is the implementation of education in the home environment, community environment, and in educational institutions as a whole, not only in formal educational institutions only. Consequently, the need for learning innovation together in realizing an educated generation with smart and moral potential. Educational tips need to promote tolerant education in order to become a fanatic generation in dealing with differences in ethnicity, religion, and social strata in their environment. This effort is reinforced by the fact that terrorist networks have become an epidemic of acute illness in this country. In fact, the majority of educated perpetrators of terror, both formal education and non-formal religious education (Islamic).

Keywords: education and awareness of differences

\section{A. Pendahuluan}

Konstelasi tata dunia yang terus memproduksi perang, kekerasan, dan ketidakadilan memberi pesan dan pelajaran berharga bagi kita untuk merawat kebhinekaan sebagai aset berharga. Perawatan dapat dilakukan dengan memupuk dan penyerbukan semua potensi perbedaan dengan dasar menyadari realitas yang berbeda, di antaranya dengan pendidikan toleransi. Perbedaan realitasnya adalah keniscayaan agar bangunan negara-bangsa tak terkoyak. Kerja besar merajut pengertian dan kesepahaman persatuan dalam keragaman merupakan panggilan tugas semua pihak yang pandai mensyukuri berkah kemajemukan sebagai warisan peradaban dan ketatanegaraan kita. Hal ini ditanamkan sejak di bangku pendidikan. Bekal utama yang kita miliki adalah sikap toleran, solidaritas, gotong royong, dan bekerjanya 


\section{QUALITY}

Volume 5, Nomor 1, 2017: 104-139

kearifan lokal yang kesemuanya tertanam sejak era leluhur. Akan tetapi, bangunan yang kokoh itu rentan disusupi virus negatif kehidupan sehingga muncul konflik yang diawali adanya kesenjangan sosial berdampak ketidaksetaraan sosial dan ketimpangan ekonomi yang berdampak dominasi pihak tertentu atas pihak lain.

Dalam konteks Indonesia, demokrasi menjadi pilihan tata perpolitikan nasional. Konsekuensinya, terpenuhinya kepentingan rakyat sebagai tolok ukur utamanya. Demokrasi bukanlah semata-mata persoalan sistem politik, melainkan pandangan hidup yang diwujudkan dalam kehidupan nyata, terutama soal proses pembuatan keputusan yang terkait dengan kehidupan warga negara. Demokrasi dijadikan kontrol rakyat atas urusan publik dengan berpijak pada tujuan bernegara. Urusan publik mencakup soal kebijakan politik terkait kebutuhan dan pelayanan yang diterima warga negara dari negara. Era Reformasi menjanjikan masa depan bersama yang lebih baik. Akan tetapi, pada tataran realitas, sejauhmana keberpihakan negara pada warga negara, khususnya yang berposisi kurang beruntung. Dengan demikian, sudah seharusnya kinerja pemerintah dievaluasi oleh publik. Kinerja pemerintah yang dievaluasi dalam naskah ini adalah menjaga kenyamanan dan keamanan warganya. Kinerja tersebut dapat terpublikasikan atas peran media massa.

Menurut Sirry, berbagai survei menunjukkan tingkat intoleransi agama di dunia naik cukup tajam. Di negara Barat, secara nominal mayoritas beragama Kristen, lebih dari 50 persen berpandangan keagamaan yang eksklusivis. Begitu pula di Afrika dan Tiongkok yang mana perkembangan agama Kristen berkembang pesat, sekitar 80 persennya eksklusif. Di negara yang mayoritas muslim, seperti Indonesia dan Turki yang dianggap paling moderat pun, 65 persen muslimnya berpandangan eksklusif. Dengan demikian, revitalisasi (bangkitnya umat beragama dalam beragama) dikhawatirkan menyebabkan guncangan pada masa depan kehidupan. Maka ada solusi yang ditawarkan publik dengan menyempitkan ruang gerak agama, yakni disingkirkan ke ruang privat saja. Dalihnya, semakin modern suatu masyarakat semakin tidak memberi ruang bagi peran publik agama. Dalam pandangan Sirry, eksklusifisme agama adalah keyakinan seseorang bahwa agamanya adalah satu- 


\section{QUALITY}

Volume 5, Nomor 1, 2017: 104-139

satunya jalan menuju keselamatan dan yang lain sesat. Adapun pluralisme agama berpandangan bahwa semua agama sebagai jalan yang sah, sedangkan pluralisme politik merupakan pemikiran politik yang mengejawantah dalam institusi yang mengakui hak-hak sipil dan politik warga secara sama, terlepas dari perbedaan suku, agama, ras, dan antargolongan (SARA). Adapun eksklusivisme politik tidak memperhatikan netralitas terhadap isu SARA, tetapi memihak ideologi tertentu, agama tertentu, atau etnik tertentu dengan menggunakan mekanisme paksaan untuk mengeksklusi yang lain. Pandangan umum, orang yang eksklusif beragama tak akan pernah menjadi pluralis dalam politik karena eksklusifisme politik sebagai perwujudan eksklusifisme beragama dan pluralisme politik sebagai pluralisme agama. Benarkah hubungan keduanya bersifat kausalitas? Intensitas perjumpaan dalam masyarakat pluralis berujung pada terkikisnya eksklusifisme beragama sehingga pandangan keagamaan menjadi pluralis, tak ada lagi hambatan untuk menjadi pluralis secara politik. Semakin intensnya pergaulan lintas agama dan komunitas, semakin terkikis pandangan yang mengeklusi yang lain dan membuka sikap politik yang pluralis. Eksklusifisme agama tidak sepenuhnya bertolak belakang dari pluralisme politik. Minimal, eksklusifisme beragama tak dipandang sebagai biang kerok eksklusifisme politik yang tak memberi ruang bagi pemenuhan hak sipil warga. Eksklusifisme agama dan eksklusifisme politik tidak bersifat langsung sebagaimana umum dipersepsikan (Sirry, 2016:7). Eksklusif merupakan tahap awal munculnya benih-benih radikal. Bila tak terkontrol maka berpeluang menjadi pelaku teroris meski pernah dididik di lembaga pendidikan agama yang formal dan nonformal.

Pelaku teror (kelompok ekstrimis) menurut Syafii Maarif, tak memiliki visi tentang kehidupan yang damai di bumi. Mereka lebih memendam angan dan igauan tentang kehidupan bersama bidadari di alam setelah kematian nanti. Ini merupakan teologi sesat karena kehidupan bahagia di akhirat harus dilalui dengan kehidupan yang saleh dan bermanfaat di muka bumi. Kegagalan sebagian orang yang menganut teologi kekerasan atas nama agama ini dalam memahami ajaran agamanya telah 
QUALITY

Volume 5, Nomor 1, 2017: 104-139

menuntunnya pada perbuatan konyol melakukan perusakan dan kebinasaan (2017:19).

Permasalahan dalam naskah ini adalah faktor apakah yang memicu tumbuhnya gerakan radikal?, bagaimana peta teroris di Kudus? dan bagaimana urgensi pendidikan toleransi sebagai upaya menangkal radikalisme? Manfaat yang diharapkan dengan naskah ini adalah untuk memahami faktor yang memicu tumbuhnya gerakan radikal di Kudus, untuk mengetahui peta teroris di Kudus, dan urgensi pendidikan sebagai upaya menangkal radikalisme. Dipilihnya Kudus sebagai lokus riset dengan pertimbangan, pertama, Kudus dikenal kota santri dan banyak lembaga agama Islam dan ulama. Akan tetapi, di Kudus pula ada oknum pelaku teroris, meski tatkala menjadi pelaku, mereka statusnya bukan lagi warga Kudus, hanya saja, lahir di Kudus dan keluarganya di Kudus. Padahal mereka pernah dididik di lembaga keagamaan Islam di Kudus. Kondisi tersebut, tatkala mereka tewas akibat ulah terornya, mereka dimakamkan di Kudus yang diawali pro-kontra oleh warga Kudus, meski akhirnya dimakamkan pula di Kudus. Padahal, daerah lain yang menolak pemakaman pelaku terror meski si pelaku lahir dan besar di daerah itu. Penolakan dengan dalih citra negatif sebagai daerah dimakamkannya teroris.

Sikap intoleransi yang kian merebak sehingga muncul keresahan akibat maraknya pemikiran dan perilaku intoleran. Hal ini memunculkan gerakan 300 antropolog se-Indonesia yang tergabung dalam Gerakan Antropolog untuk Indonesia yang Bineka Inklusif (AUI) bersuara. Mereka diterima Presiden Jokowi di Istana Merdeka Jakarta, Senin 16 Januari 2017. AUI beranggapan, bila kita gagal mengelola keberagaman, usia Indonesia tinggal 10 tahun lagi. Ada tiga pangkal persoalan intoleransi, yakni sejak di dunia pendidikan mulai PAUD hingga perguruan tinggi, adanya ketimpangan perekonomian dan kesejahteraan,serta ketidakadilan ekonomi. Di sisi lain, kurikulum pendidikan agama lebih menekankan hapalan dan ritual, kurang membahas permasalahan yang dihadapi siswa sehari-hari. Dampaknya, siswa mencari informasi dari sumber lain seperti teman sebaya atau internet yang tak terjamin kebenarannya. Peningkatan mutu yang diterima guru dalam forum pelatihan 


\section{QUALITY}

Volume 5, Nomor 1, 2017: 104-139

berupa optimalisasi metode pembelajaran, bukan membahas isu kontemporer dan jalan penyelesaian, seperti idealitas kehidupan lintas iman dan SARA, dsb.

\section{Landasan Teori}

\section{Gerakan Radikal}

Radikal merupakan gerakan menghendaki perubahan secara ekstrim, deradikalisasi adalah gerakan berkebalikan dengan radikal dan deideologisasi (melepaskan ideologi). Menurut Golese, deradikalisasi dengan pendekatan humanis, soul approach, dan menyentuh akar rumput (2009:122). Paham radikalisme menjangkit semua elemen sosial, termasuk kalangan mahasiswa dan sarjana. Menurut Bakti, gerakan radikal di kampus disebabkan oleh dua faktor utama. Pertama, latar belakang pemahaman keagamaan yang tekstual dan sepotong-potong. Biasanya dari kampus sekuler (non-keagamaan) mudah terperangkap oleh fundamentalisme dan eksklusivisme keberagamaan, terutama dari fakultas sains. Akan tetapi, perguruan tinggi bercorak keislaman (UIN/IAIN/STAIN) pun ada yang terlibat. Hal ini karena adanya perubahan orientasi dan ekspansi keilmuan yang bersifat umum. Doktrin yang ditanamkan bahwa Indonesia adalah negara dengan penguasa zalim (thoghut) yang tak wajib dipatuhi dan mesti diperangi. Kedua, faktor ketimpangan dan ketidakadilan sosial, politik, dan ekonomi yang masih mengakar dalam masyarakat. Kelompok yang tak berdaya mudah disulut dan ditunggangi oleh kelompok radikal. Langkah yang perlu dilakukan, menurut Bakti, pertama, dirjen pendidikan tinggi bekerja sama dengan perguruan tinggi membuat program bina damai keberagamaan di kampus, seperti sosialisasi pemahaman yang toleran, inklusivisme, multikulturalsime, dan bahaya paham radikal sebagai upaya preventif. Kedua, merevitalisasi kurikulum dan mengevaluasi pengajaran setiap semester, terutama terkait mata kuliah yang bersifat ideologis, seperti Pancasila, pendidikan kewarganegaraan, dan pendidikan agama. Mata kuliah itu selama ini berkutat pada aspek kognisi, belum menyentuh aspek afeksi dan sikap. Ketiga, kampus bekerja sama dengan organisasi kemahasiswaan ekstrakampus yang relatif moderat dalam membantu mencairkan pemahaman gerakan radikalisme ditengarai akibat tumbuh suburnya organisasi lembaga dakawah kampus 


\section{QUALITY}

Volume 5, Nomor 1, 2017: 104-139

yang bersifat eksklusif (2016:7). Hal yang perlu digarisbawahi dari Bakti bahwa perlunya mengevaluasi pengajaran sehingga naskah ini terfokus pada upaya mengevaluasi proses pembelajaran agar benih radikalisme tertangani dengan pendekatan preventif.

Aksi terorisme tak akan berhenti jika program pemberantasannya masih menyisakan struktur kesempatan (opportunity structure) berseminya kembali ideologi radikalis-teroris. Struktur kesempatan maksudnya adalah berbagai kondisi struktur yang menyisakan ruang kosong dan dapat memantik kemunculan ideologi radikalisme terorisme. Kemiskinan, pengangguran, kesenjangan ekonomi, deprivasi sosial-politik, kebijakan negara yang salah, dan konstelasi geopolitik global adalah contohnya. Dapat pula berbentuk penciptaan mitos 'kesyahidan' baru di kalangan teroris akibat aksi Densus 88. Ada aksi ada reaksi sehingga semakin keras tekanan pemerintah pada teroris, semakin keras pula resistensinya (perlawanannya) pada pemerintah dengan menyasar pada Densus 88 polri dan polisi lainnya. Dibutuhkan paradigma baru pemberantasan teroris yang tak hanya mengandalkan pendekatan keamanan, perlu program pengawasan (surveillance), deradikalisasi, pemulihan, dan inklusi sosial eks-narapidana teroris untuk memutus mata rantai reproduksi ideologi teroris dan menghentikan peluang perekrutan anggota baru. Perlunya pemerintah menyinergikan institusinya yang menjadi garda depan program deradikalisasi dalam kebijakan yang terintegrasi. Ada kesan tumpang tindih kelembagaan seperti Densus 88 polri, Badan Nasional Penanggulangan Terorisme (BNPT), Badan Intelijen Negara (BIN), dan Kemenkum HAM. Akibatnya, setiap unit terkesan berjalan sendirisendiri. Program deradikaliasi dan pemberantasan teroris diarahkan untuk memulihkan kehidupan sosial-ekonomi para eks-narapidana teroris. Kesulitan beradaptasi dengan masyarakat karena stigma akibat masyarakat mengisolasi diri takut dikaitkan dengan teroris atau tertular ideologinya dan kegagalan ekonominya akan melapangkan jalan kembali terlibat dalam jaringan teroris (2016:7).

\section{Deradikalisasi}




\section{QUALITY}

Volume 5, Nomor 1, 2017: 104-139

Kegagalan program deradikalisasi menurut Kritianawati disebabkan oleh (1) minimnya keterlibatan kelompok acuan dalam aktivitas program, yakni komunitas moderat, kelompok pendidikan pro-toleransi, dan ormas yang peduli pada kemajemukan, (2) lebih berorientasi pada penyadaran yang individualis dan hanya menyentuh individu pelaku teroris, (3) mengabaikan fungsi dan peran lembaga pendidikan, baik yang bersifat formal dan nonformal (2017:6).

Golese (2009:67) mendedahkan bentuk deradikalisasi di berbagai negara. Pertama, Arab Saudi dengan perang melawan ide radikal (war of ideas) yang dianut kelompok teroris berhaluan Islam radikal dengan program rehabilitasi dan reedukasi. Hal ini kategori soft power approach dan pendekatan budaya (cultural approach), tak cukup dengan cara tradisional, membuat UU antiteroris, membentuk pasukan khusus antiteroris, menangkap pelaku dan memenjarakannya atau menghukum mati. Karena teroris kategori bahaya laten maka diantisipasinya dengan program pengenalan diri (early dissemination programs). Hal tersebut menandaskan bahwa teroris perlu dilawan dengan ide, sumber ide, dan mencerahkan penerima ide yakni santri dan komunitas pesantren, tidak dengan angkat senjata. Kedua, Yaman mengadakan dialog untuk merasionalkan pemikiran teroris, menumbangkan alasan dan sebab intelektual yang dimiliki teroris. Ketiga, Mesir melawan teroris dengan kontra teroris karena pergerakan organisasi jihad tumbuh di lingkungan universitas Mesir pertengahan tahun 1970-an, sebagai bagian organisasi kemahasiswaan. Keempat, Singapura melawan teroris dengan swadaya masyarakat yang dikenal Religious Rehabilitation Group beranggotakan LSM dan komunitas umat Islam Singapura agar melakukan perlawanan terhadap Jamaah Islamiyah Singapura, sebagai sumber dan wadah diskusi antara pemerintah dengan perwakilan komunitas muslim Singapura. Kelima, Malaysia, Kolombia, Aljazair, dan Tajikistan mengagendakan deradikalisasi. Sebagaimana Indonesia dengan peningkatan gerakan penangkapan, pencegahan, dan pemberantasan teroris ditangani ekstra oleh Satgas Bom Polri.

\section{B. Pembahasan}


QUALITY

Volume 5, Nomor 1, 2017: 104-139

\section{Faktor Pemicu Gerakan Radikal Global}

Perlawan muslim pada pihak lain dengan kekerasan dipicu oleh ragam kasus. Adanya genosida yang dilakukan Khmer Merah dan tragedi Bosnia. Genosida oleh rezim Khmer Merah (1975-1979) menewaskan 2 juta rakyat. Kekejaman sebagaimana kesaksian korban selamat, Meas Sokka (55 th) dalam pengadilan. Pelaku Nuon Chea (88 th) dan Khieu Samphan (83 th) divonis hukuman seumur hidup setelah menjalani 2 tahun persidangan karena tuduhan genosida 100.000- 500.000 etnis minoritas Muslim Cham dan 20.000 orang Vietnam di Kamboja. Pembunuhan dengan memenggal kepala dan agar tak terdengar jeritan, mereka meninggikan volume musik dengan keras untuk menyamarkan jeritan. Seusai membunuh, algojo berpesta minum anggur yang dicampuri organ korban terbunuh yang dikeringkan. Rata-rata sehari 20 korban dibunuh setelah berminggu-minggu disiksa dan dibiarkan kelaparan. Pembunuhan juga pada bayi dan anak-anak dikubur secara masal oleh sipir (Kompas, 22 Januari 2015). Kekejaman tentara Serbia Bosnia 1992-1995 dengan membunuh 8.373 warga muslim Bosnia, 20 ribu hingga 50 ribu wanita diperkosa, dan 70 ribu warga diusir dari desanya pada 13 Juli 1995. Tentara yang dikomandani Ratko Mladik, Franc Kos, Branimir Manojlovic, Stanko Kojic, dan Vlatimir Golijan menjadi catatan kelam peradaban dunia. Korban dikuburkan di makam massal. Pembunuhan bertujuan menghancurkan keseluruhan atau sebagian kelompok, etnis, dan muslim di Bosnia Herzegovina. Tahun 2010 sebagai peringatan ke-15 pembantaian dengan pemakaman ulang korban perang yang teridentifikasi sebanyak 775 di Potocari, dekat Srebenica. Terdapat 6.066 korban yang digali dari kuburan massal dikuburkan kembali. Srebenica dinyatakan PBB sebagai daerah aman dan wilayah pengungsian warga Bosnia 1992-1995, tetapi tentara Bosnia membantai pria dan anak lelaki muslim di kota itu (Suara Merdeka, 12 Juli 2010). Perang di kawasan Balkan, Eropa Tenggara, setelah pasukan perdamaian KFOR pimpinan NATO memasuki Kosovo pada 12 Juni 1999 terjadi peperangan sepanjang dekade 1990-an. Terdapat 14.650 nyawa belum diketahui kondisinya sejak konflik bersenjata di 


\section{QUALITY}

Volume 5, Nomor 1, 2017: 104-139

Serbia, Bosnia-Herzegovina, Kroasia, dan Kosovo (Kompas, 31 Agustus 2010, hlm.3).

Dua tokoh paling berkuasa semasa Perang Bosnia yang berakhir pada 1990, Radovan Karadzic dan Ratko Mladic untuk pertama kalinya Selasa, 28 Januari 2014 tampil bersama di Pengadilan Kriminal Internasional untuk bekas Yugoslavia di Den Hag Belanda meski keduanya menolak dakwaan. Karadzic menghadapi 11 dakwaan, termasuk genosida yang terkait pembunuhan massal di Srebenica pada Juli 1985. Kala itu, 80.000 warga Bosnia yang mayoritas muslim di Kota Srebenica dibunuh secara keji oleh unit tempur tentara Republik Srpska di bawah komandan Jenderal Ratko Mladic. Mladic menolak bersaksi untuk meringankan Radovan Karadzic. Karadzic yang semula berprofesi sebagai dokter dan psikiater ditangkap di Beograd pada 2008 setelah 13 tahun dalam pelarian. Ia pernah memimpin negara BosniaHerzegovina yang dihuni etnis Serbia murni diyakini berperan besar dalam pembantaian muslim Bosnia di Srebenica dan Sarajevo. Mladic ditangkap pada 2011 di Serbia Utara setelah 16 tahun dalam pelarian. Pasukan Bosnia-Serbia mengepung Sarajevo selama 44 bulan, mengusir warga muslim dan Kroasia, dan meneror penduduk sipil dengan bom dan tembakan jitu (Kompas, 29 Januari 2011, hlm.9).

Konflik dipicu sentimen kelompok Serbia yang membalas Bosnia (muslim) yang dikenang sebagai perwujudan Imperium Turki Utsmani yang menduduki Serbia selama 500 tahun (Usman bin Erthogul sebagai pemimpin pertama Dinasti Utsmani). Wilayahnya membentang dari Suriah ke Danube. Turki Utsmani mampu mengembalikan kejayaan Islam di Arab selama 7 abad, mampu menaklukkan Kerajaan Mamluk dan Kerajaan Romawi Timur (Byzantium). Di antara peninggalan Turki berupa Aya Sofia yang semula gereja menjadi masjid. Pasca-konflik, dideklarasikan Negara Bosnia-Herzegovina pada 15 Oktober 1991 terdiri etnis muslim Bosnia 44 \%, Ortodoks Serbia 31\%, Katolik Kroasia 17\%. Pada 29 Februari 1992 dilakukan referendum kemerdekaan Bosnia-Herzegovina yang dimenangkan

kelompok Bosnia. Referendum diboikot kelompok Bosnia-Herzegovina yang menghendaki unifikasi wilayah-wilayah Serbia, yang mencakup sebagian Bosnia- 


\section{QUALITY}

Volume 5, Nomor 1, 2017: 104-139

Herzegovina. Kelompok Bosnia-Serbia didukung pemerintah Serbia (pimpinan Slobodan Milosevic) dan tentara Yugoslavia (Yugoslavia People's Army) menyerang Bosnia-Herzegovina dengan tujuan membersihkan wilayah Serbia yang mencakup sebagian Bosnia-Herzegovina. Pasukan PBB di antaranya pasukan Belanda tak mampu menahan pasukan Serbia. Pada 27 Februari 2007 Mahkamah Internasional menetapkan tragedi di atas sebagai genosida (pembasmian etnis muslim) terbesar di Eropa sejak PD II dan kejadian pertama yang ditetapkan sebagai genosida secara hukum. Pada 16 Juli, Pengadilan Distrik di Den Haag Belanda memutuskan bahwa Belanda bertanggung jawab atas 300 orang yang dibantai. Belanda dinilai gagal melindungi warga etnis Bosnia atas pembantaian yang dilakukan etnis Serbia. Hasil keputusan Hakim Larissa Elwin yang hanya bertanggung jawab 300 orang diprotes oleh keluarga korban. Pada April 2014, Pemerintah Belanda setuju membayar 20 ribu euro kepada kerabat dari 3 orang muslim Bosnia yang dibunuh setelah pasukan penjaga perdamaian mengusir mereka dari kompleks PBB (Kompas, 24 Agustus 2014).

Kroasia yang kini bergabung dengan Uni Eropa sejak Juni 2013 mengajukan tuduhan genosida pada Belgrade dan Serbia pada 1999. Akan tetapi, Mahkamah Internasional PBB Selasa 3 Januari 2015 menyatakan bahwa Kroasia maupun Serbia sama-sama tidak terbukti melakukan genosida selama perang di Yugoslavia pada 1991-1995 berdasarkan voting 15 suara hakim menolak dan 2 hakim menyetujui adanya genosida. Kasus tersebut merupakan bagian dari pecahnya Yugoslavia menjadi 7 negara bagian akibat perang yang menewaskan 13.000 jiwa yang merupakan perang terbesar di Eropa sejak PD II dan 200.000 orang Serbia melarikan diri setelah pertempuran berakhir. Argumen penolakan hakim, tindakan pembersihan etnis mungkin menjadi bagian dari genosida, namun hal itu akan dilakukan jika ada tujuan menghancurkan secara fisik kelompok yang menjadi target (Suara Merdeka, 4 Februari 2015).

Ketegangan yang diderita muslim di Amerika pun tak terwujud. Otoritas Washington, Rabu 2 Juli 2014 menyatakan meningkatkan keamanan di beberapa 


\section{QUALITY}

Volume 5, Nomor 1, 2017: 104-139

bandara yang mempunyai penerbangan langsung ke Amerika. Di tengah kekhawatiran bahwa teroris mengembangkan bom baru yang bisa diselundupkan ke pesawat. Para pembuat bom dari Nusra Front, cabang Al Qaeda di Suriah dan Al Qaeda di Semenanjung Arab (AQAP) yang berbasis di Yaman diperkirakan bekerja sama mengembangkan bahan peledak yang bisa menghindari deteksi sistem skrining bandara. Menteri Keamanan Dalam Negeri AS Jeh Johnson mengumumkan langkah yang diambil yakni menambah pemeriksaan sepatu dan barang milik penumpang. Badan Keamanan Transportasi memberlakukan langkah menyongsong hari libur dan hari kemerdekaan AS 4 Juli 2014 (Kompas, 4 Juli 2014). Otoritas Perancis Jumat 4 Juli 2014 mengikuti anjuran Amerika untuk memperketat pengecekan terhadap para penumpang dan barang bawaan yang masuk ke Eropa dan Timur Tengah, begitu pula Inggris. Hal ini terjadi di tengah pelarangan warga muslim Palestina dari Tepi Barat masuk Jerusalem Timur untuk Jumatan pertama pada bulan Ramadan dan lelaki Palestina di bawah umur 50 tahun masuk kompleks Masjid Al Aqsha oleh Israel (Kompas, 5 Juli 2014). Pasca-pengeboman World Trade Center (WTC) pusat bisnis di Amerika pada 11 September 2001 masih memunculkan kecurigaan Amerika terhadap warga muslim dunia dengan program kontraterorisme. Kepolisian New York AS merekrut para imigran -sebagian besar muslim- untuk dijadikan informan yang memata-matai aktivitas di kafe, resto, dan masjid. Para imigran tersebut berprofesi sebagai penjual makanan keliling asal Afganistan, sopir asal Mesir, dan pelajar asal Pakistan. Sebagian imigran yang dijadikan informan polisi Amerika ditangkap dalam kasus-kasus kecil seperti tiket parkir. Perekrutan detektif swasta tersebut sebagai upaya dini AS mengetahui pihak yang memberikan pandangan soal dunia terorisme (Kompas,12 Mei 2014).

Di tengah fakta tersebut, publik terutama muslim dunia mendapatkan produk penegakan hukum yang menyegarkan, yakni Dewan Negara, pengadilan administrasi tertinggi di Perancis, Jumat 26 Agustus 2016 menangguhkan larangan pemakaian burkini (baju renang perempuan yang menutupi seluruh tubuh) di kota VilleneuveLoubet, Perancis Tenggara. Dalih Dewan Negara, pelarangan itu jelas ilegal terhadap 


\section{QUALITY}

Volume 5, Nomor 1, 2017: 104-139

kebebasan dasar. Otoritas lokal hanya bisa mengeluarkan kebijakan yang membatasi kebebasan individu jika pemakaian burkini di pantai memunculkan risiko ancaman pada ketertiban masyarakat. Semula, dalih pelarangan didasarkan alasan bahwa pemakaian burkini bertentangan dengan UU Perancis soal sekularisme. Pelarangan itu menyusul serangkaian serangan mematikan kelompok militan di Paris.

Sidang Umum PBB di New York 23 September 2010, Presiden Iran saat itu Mahmud Ahmadinejad menegaskan teori konspirasi serangan teroris 11 September 2001 di New York dan Washington bahwa AS terlibat serangan atau membiarkan? Serangan untuk membalikkan kemenangan ekonomi AS dan pengaruhnya di Timur Tengah demi menyelamatkan rezim Zionis. Tatkala Ahmadinejad berpidato pada Sidang Umum PBB di New York 11 September 2010 perwakilan AS, Inggris, Swedia, Australia, Belgia, Uruguay, dan Spanyol keluar dari ruang sidang (Obama berpidato pagi hari, Ahmadinejad sore harinya). Ahmadinejad meminta PBB membentuk tim pencari fakta independen menyelidiki serangan 9 November 2001 dengan memaparkan 3 teori (1) teori konspirasi, serangan dilakukan organisasi teroris yang kompleks dan amat kuat, bahkan menembus intelijen dan pertahanan AS yang dilindungi pejabat AS, (2) segelintir orang pada pemerintahan AS merancang serangan untuk membalikkan perekonomian AS yang menurun. Mereka ingin mencengkeramkan kukunya di Timur Tengah dan rezim Zionis, (3) AS mengalokasikan dana 80 miliar dollar AS untuk mempercanggih senjata nuklir (Suara Merdeka, 25 September 2010). Ketakutan Barat pada Islam bukan tanpa alasan, muslim di Uni Eropa makin meningkat jumlahnya. Data 2009, 5 persen total penduduk Uni Eropa (27 negara) adalah muslim. Diperkirakan 2015 meningkat dua kali lipat dan 2050 diperkirakan 20 persen (seperlima) karena imigrasi dan rendahnya tingkat kelahiran warga kulit putih dan meningkatnya kelahiran muslim di Eropa. Indikatornya banyak bayi yang bernama islami (Mohamed, Adam, Rayan, Ayoub, Mehdi, Amine, Hamza, dsb.). Nama Mohamed digunakan untuk bayi lelaki di Belanda di Kota Den Haag, Amsterdam, Rotterdam, dan Utrecht. Angkatan Udara AS tahun 2006 meriset terkait populasi muslim di Eropa bahwa sekurangnya 15 juta 


\section{QUALITY}

Volume 5, Nomor 1, 2017: 104-139

muslim di Uni Eropa dan ada kemungkinan mencapai 23 juta. Sementara warga kulit putih akan menjadi minoritas di Birmingham Inggris tahun 2026. Hasil riset lain menyatakan, jumlah warga muslim melebihi nonmuslim di Perancis dan di seluruh wilayah Eropa Barat pada pertengahan abad ini. Austria yang 90 persen penduduknya Katolik abad ke-20 akan berubah dan tahun 2050 Islam diperkirakan menjadi mayoritas pada kelompok usia di bawah 15 tahun (Republika, 30 Desember 2010).

Mengantisipasi pertumbuhan jumlah muslim di Eropa karena imigran maka bangkitnya partai ekstrim kanan di Eropa sebagai upaya melestarikan warisan budaya Eropa yang bernuansa demokratik Kristen atau nasionalisme, sehingga muncul aliansi Pan-Eropa (Inggris, Norwegia, Denmark, Belanda, Prancis, Swiss, Italia, Austria, Bulgaria, Hungaria, Jerman, Swedia). Hal ini didukung kemenangan partai ekstrim kanan dalam pemilu parlemen, seperti Jobbik di Hungaria, Front Nasional di Perancis, Partai Nasional di Inggris, dan pendirian gerakan aliansi nasional Eropa. Kelompok radikal ekstrem kanan di sejumlah negara Eropa mendapat dukungan dari kelompok liberal konservatif secara finansial ataupun politis. Pemimpin negara Eropa juga memberi kontribusi bagi berkembangnya sikap anti-imigran, seperti Perdana Menteri Italia, Silvio Berlusconi yang menciptakan koalisi partai sayap kanan bernama Forza Italia. Mereka mengusir kaum Gipsi telebih dahulu sebelum hal yang sama dilakukan oleh Presiden Perancis, Nicolas Sarkozy. Tahun 2000 Perancis mengusir warga Rumania di negaranya dengan ragam dalih. Tokoh konservatif Bavaria, Horst Seehofer, menyerukan penangguhan imigran warga Turki dan Timur Tengah ke Jerman karena dianggap tak mampu berintegrasi dengan budaya Jerman. Kecurigaan tak surut, sebuah masjid di Kota Eskilstuna, Swedia, Kamis 25 Desember 2014 dibakar, 5 dari 20 orang yang salat dzuhur dilarikan ke rumah sakit karena menghirup asap tebal. Pembakaran terjadi di tengah perdebatan soal imigran muslim di Swedia sejak Desember 2013. Sayap kanan yang anti-imigran mengusulkan pemotongan anggaran bagi pencari suaka sampai 90 persen. Mereka menolak pada Partai Utama yang mempertahankan kebijakan liberal. Pada Desember 2013, kelompok neo-nazi menyerang aksi damai anti-rasisme. Di Jerman, gerakan warga 


\section{QUALITY}

Volume 5, Nomor 1, 2017: 104-139

Eropa Patriotik anti-islamisasi di Barat (Pegida) sejumlah 17.500 yang cemas karena ada 200.000 pengungsi dari Timur Tengah khususnya Suriah mengungsi ke Jerman. Pegida mendemo imigran pada Senin 15 Desember 2014 di Dresden, Jerman bagian timur, meski Kanselir Jerman Angela Merkel mengecam karena Jerman memerlukan imigran untuk mengatasi ancaman krisis demografi akibat rendahnya kelahiran. Senin 5 Januari 2015 sekitar 18.000 pengunjuk rasa di Dresden turun ke jalan memprotes fanatisme dan radikalisme beragama. Di beberapa kota lebih dari 22.000 orang beraksi menentang yang anti-asing. Munculnya kelompok militan yang berafiliasi (bergabung) dengan Al-Qaedah di Irak dapat dirunut jejaknya sejak invasi Inggris dan Amerika di Irak semasa Presiden AS George W Bush Maret 2003. Upaya ekstremis itu untuk melawan/membalas pihak yang membantu sekutu (AS dan Inggris). Sebagaimana upaya kelompok Al-Shehab membunuh 50 warga Mpeketoni Kenya Timur Minggu 15 Juni 2014, sebagian korban menonton bola Piala Dunia di Brazil via tv. Pengakuan Al-Shehab, serangan membalas keterlibatan tentara Kenya yang ikut memerangi milisi di Somalia. Pada September 2013 tentara Al-Shehab dibunuh oleh tentara Kenya yang berkoalisi dengan 22.000 tentara Uni Afrika, pihak AlQaeda 67 orang tewas, dan Al-Shehab membalasnya (Kompas, 17 Juni 2014).

Sejak Pakistan menggelar operasi militer untuk mengusir kelompok milisi Taliban Pakistan dan militan Uzbek di wilayah Waziristan Pakistan Juni 2014, 350.000 warga sipil mengungsi dan mengantri mendapat izin aparat keamanan menuju ke Bannu. Pakistan mengusir milisi karena serangan milisi terhadap Bandar Udara Internasional Jinnah di Karachi (Kompas, 23 Juni 2014). Faktor mengungsi karena upaya penyelamatan diri dan keluarga atas arogansi pemerintah di dalam negeri karena tak menemukan kenyamanan hidup di negerinya, meski di negara tujuan diusir. Pengungsi Somalia, Iran, dan Sudan mencari suaka di Australi dialihkan ke Papua Nugini. Pengungsi menolak penempatan oleh Australia karena warga Papua pun menolak kedatangannya dan penempatan di Papua secara permanen. Pengungsi mendemo dengan mogok makan. Di bawah pemerintahan Toni Abbott, Australia tak mengizinkan pengungsi di wilayahnya karena Australia 


\section{QUALITY}

Volume 5, Nomor 1, 2017: 104-139

mewaspadai teroris dan makin meningkatnya jumlah orang Australia yang berhubungan atau terinspirasi teroris. Satu hal yang harus dipahami bahwa istilah 'kelompok teroris' pada dasarnya klaim Amerika bagi pihak yang tak tunduk atas arogansinya sebagai panglima dunia. Jadi, kita pun terlanjur menerima anggapan Amerika bagi pihak yang menentang kelalimannya. Keberhasilan julukan karena peran media Barat yang disetir kapitalis. Kita pun latah mengikuti anggapan yang salah. Padahal, eksisnya ekstrimis karena luka lama akibat arogansi sekutu di Timur Tengah tujuannya menghancurkan Islam dengan dalih membasmi teroris. Bila tak ada arogansi merampas ekonomi dan merusak kenyamanan muslim dunia, teroris pun tak akan ada.

\section{Radikalisme Membidik Lembaga Pendidikan}

Setiap jengkal waktu, muslim dunia harus siap menghadapi berita buruk yang sengaja dihembuskan oleh pihak yang mengadu domba. Tujuannya terjadi konflik atas nama agama. Pada Kamis 4 September 2014, Menteri Agama Lukman Hakim Saifuddin melakukan tabayun (klarifikasi) pada Duta Besar Arab Saudi untuk Indonesia Mustofa bin Ibrahim al Mubarok di Jakarta. Klarifikasi berkaitan isu pemindahan makam Nabi SAW oleh Pemerintah Arab Saudi. Jawaban Dubes sudah dapat diduga bahwa hal itu isu yang tak benar adanya pemindahan makam Nabi dari Masjid Nabawi di Madinah ke Makam Baqi. Dengan demikian, umat Islam tak perlu merespon berlebihan. Bila merespon berlebihan, dijadikan umpan empuk pihak lain untuk selalu memberi bahan provokasi. Mengapa selalu muncul isu bohong? Tujuan utamanya menghancurkan kekokohan muslim dunia dengan beragam cara. Serangan serupa secara massif disasarkan pada anak didik di bangku sekolah. Tahun 2016, di Bandung Jawa Barat dan Jombang Jawa Timur beredar buku Kumpulan Lembar Kerja Peserta Didik Pendidikan Agama Islam Kelas XI SMA. Buku tersebut dengan kutipan 'diperbolehkan membunuh orang musyrik'. Dinas Pendidikan dan Kebudayaan Kabupaten Semarang menarik buku pendidikan agama Islam dan budi pekerti untuk siswa kelas XI SMA/sederajat karena pada halaman 170 poin A menyebutkan "yang boleh dan harus disembah hanyalah Allah SWT dan orang yang 


\section{QUALITY}

Volume 5, Nomor 1, 2017: 104-139

menyembah selain Allah SWT telah menjadi musyrik dan boleh dibunuh". Buku bagi sekolah yang menerapkan kurikulum 2013. Fakta ini menegaskan bahwa siswa di sekolah formal (terutama sekolah umum) menjadi tarjet utama penyebaran paham radikal. Untuk menghindari adanya konten negatif dalam buku yang diperuntukkan bagi anak didik, Mendikbud melakukan tata kelola buku yang beredar, terutama buku pelajaran. Buku pendidikan agama yang mengandung ajaran intoleran dikhawatirkan menjadi pintu masuk untuk menyusupkan pemahaman keagamaan radikal dalam masyarakat.

Dalam aspek lain, dipicu kerisauan para guru agama karena muridnya menjadi aneh, Ciciek Farha meneliti di Jember tahun 2006 Religiusitas Kaum Muda: Studi di Tujuh Kota bahwa proses konservatisasi dapat muncul dari institusi sekuler yakni sekolah umum, khususnya di tingkat SLTA melalui kegiatan keagamaan ekstrakulikuler (EK), di bawah bidang ketakwaan OSIS. Pada tahun 1980-an EK keagamaan lebih bersifat kultural keagamaan sebelumnya berubah menjadi politikideologis yang melibatkan lembaga swadaya, termasuk alumni dan guru. Menurut Ciciek, hal ini ditengarai antara lain sebagai tanggapan terhadap politisasi agama sejak Orba. Ciciek mengingatkan (1) Dani, pelaku bom bunuh diri di Hotel J.W. Marriot Jakarta tahun 2009 adalah mantan ketua EK Keagamaan di sekolah, (2) kaderisasi dan kegiatan keagamaan di sekolah umum menggunakan metode 'cuci otak' dikemas untuk menciptakan musuh bayangan dan kebencian kepada orang lain. Solidaritas dibangun berdasarkan agama, bukan berdasarkan kebangsaan dan kemanusiaan.

Hasil survei Lembaga Kajian Islam dan Perdamaian Oktober 2010-Januari 2011 pada 100 SMP dan SMA umum, 59 sekolah swasta, dan 49 sekolah negeri di Jakarta dan sekitarnya, dari 590 responden guru agama, 28,2 persen menyatakan setuju dan sangat setuju atas aksi kekerasan atas nama agama dan moral. Konservatisme dan radikalisme atas nama agama bergerak seperti bola salju. Hasil penelitian Interfidei Yogyakarta memperlihatkan proses yang sama di beberapa sekolah umum lain (Kompas, 10 Juni 2011). Rangkaian fakta tersebut mengilhami 


\section{QUALITY}

Volume 5, Nomor 1, 2017: 104-139

Asosiasi Guru Pendidikan Agama Islam (AGPAI) Jawa Timur merekomendasikan kepada pemerintah (Kemenag, Kemendagri, dan pihak terkait) untuk membentuk peraturan pemerintah (PP) guna menanggulangi tumbuhnya gerakan Nasional Islam Indonesia (NII) dan berfungsi membatasi gerakan radikalisme, terorisme, dan ajaran sesat di Indonesia. Rekomendasi ditandatangani oleh 150 anggota (Republika, 13 Juni 2011, hlm.12). Penelitian Wahid Institute (2016) perihal indicator toleransi dan kerukunan sosial keagamaan di komunitas muda menyebutkan, ada kecenderungan meningkat 37 persen pandangan anak muda (termasuk siswa) yang mendukung praktik radikalisme. Dari 1.200 responden generasi muda yang di dalamnya juga anak musa siswa sekolah menengah, 15 persen setuju praktik pelarangan ibadah kelompok yang dianggap sesat dan minoritas, 12,5 persen setuju ideologi Pancasila diganti ideologi agama. Lebih mengejutkan, 7,9 persen setuju dengan tindakan kekerasan atas nama agama. Riset Lembaga Kajian Islam dan Perdamaian (LaKIP) bahwa pandangan intoleran makin menguat di lingkungan guru pendidikan agama Islam dan pelajar. Hal ini terbukti dengan dukungan perusakan dan penyegelan tempat ibadah (guru 24,5 persen dan siswa 41,1 persen), perusakan rumah atau fasilitas anggota keagamaan yang dituding sesat (guru 22,7 persen, siswa 51,3 persen), perusakan tempat hiburan malam (guru 28,1 persen, siswa 58,0 persen), pembelaan dengan senjata terhadap umat Islam dari ancaman agama lain (guru 32,4 persen, siswa 43,3 persen).

\section{Peta Teroris}

Tiga tantangan dihadapi umat Islam di seluruh dunia untuk dijawab, yakni sikap ketidakadilan, persepsi negatif terhadap Islam, dan aksi terorisme. Ketidakadilan yang masih berlangsung di tingkat dunia membuat umat Islam dan beberapa kalangan umat lain mengalami hal-hal yang tidak diinginkan. Termasuk penderitaan seperti kemiskinan, kesenjangan, dan lain-lain yang masih dirasakan umat Islam di seluruh dunia. Persepsi yang tidak benar dari sebagian kalangan terhadap umat Islam sering kali mudah menyimpulkan bahwa Islam adalah agama yang menyebarkan kekerasan. Ini mengakibatkan berjangkitnya penyakit islamofobia. Aksi terorisme merupakan 


\section{QUALITY}

Volume 5, Nomor 1, 2017: 104-139

bentuk menjalankan ajaran Islam yang menyimpang akidah untuk mencapai tujuan mereka. Umat Islam harus berjuang untuk meraih keadilan dunia dengan cerdas dan tepat tanpa menimbulkan masalah baru yang justru merugikan Islam. Pelaku teroris di Indonesia (nyaris) 90 persen adalah muslim. Presiden SBY (saat itu) menandasan, agar umat dibimbing untuk dapat menjalankan ajaran Islam yang benar. Misalnya, apa pengertian jihad yang benar menurut Islam? Apakah benar, ketika membunuh saudara-saudaranya yang tidak bersalah itu, surga balasannya? Termasuk melaksanakan aksi bunuh diri. Dengan begitu, persoalan yang timbul akibat penyimpangan pelaksanaan ajaran Islam dapat teratasi (Kompas, 28 Juni 2011, hlm.4).

Sudah saatnya, tokoh agama, ulama, dan pemimpin organisasi kemasyarakatan Islam di Tanah Air untuk membimbing umatnya dalam menciptakan tatanan kehidupan bermasyarakat yang harmonis, membangun akhlak mulia, dan sikap positif dalam menghadapi tantangan global dengan merujuk pada al-Quran. Hal itu dibuktikan dengan perilaku yang damai, ramah, dan toleran. Pada era global yang penuh dinamika ini, umat Islam wajib menguasai pemahaman yang utuh terhadap nilai keutamaan universal yang bersumber dari alquran dan hadis. Nilai islami dan spirit qurani perlu dijadikan rujukan pergaulan internasional, terutama di tengah arus pergeseran nilai, norma, dan perilaku kemanusiaan saat ini. Di sisi lain, eforia global di antaranya mengusung prinsip demokrasi, sebagian kita latah (menafsiri tanpa kendali) dan merambah dalam berkeyakinan. Hal itu berimbas pada diri dan kelompok dalam berbuat anarkis dianggapnya kebebasan hingga menyebabkan rusaknya citra agama. Hal ini karena tindakan non-manusiawi (non-islami) hanya dengan menafsirkan nas secara tekstual sebagai pembenar dan tindakannya didukung semangat hiperfundamentalis. Jika dipotret ke belakang, gerakan fundamentalisme di negeri ini telah lama bercokol.

Pasca-proklamasi kemerdekaan, lahirlah Gerakan DI-TII yang selanjutnya menjelma menjadi NII yang berambisi mendirikan negara Islam di NKRI. Lahirnya gerakan fundamentalis dipengaruhi oleh pemikiran yang lahir di Timur Tengah, 


\section{QUALITY}

Volume 5, Nomor 1, 2017: 104-139

seperti paham radikal Al-Ihwan al-Muslimin yang didirikan oleh Hassan Al-Banna dan dikembangkan oleh Sayyid Qutub menyebar melintasi batas dunia. Mereka beranggapan bahwa negara yang tidak menjalankan syariat Islam dianggap pemerintahannya kafir dan masyarakatnya disebut jahiliyah, pemerintahan tersebut wajib diperangi. Begitu pula gerakan penegak syariat Islam yang dimotori Taqiyuddin An-Nabhani berasal dari Palestina dengan Hizbut Tahrir-nya dan Muhammad bin Abdul Wahab an-Najdi yang mengafirkan pengikut lainnya (Syiah, Muktazilah, Jabariyah, dsb.) karena tak sepaham dengannya, dalihnya memurnikan ajaran Islam. Adapun adanya tuduhan bahwa ajaran Wahabi sebagai pemicu terorisme tak berdasar dengan bukti Taliban beraliran Islam Sunni, sedangkan AlQiadah beraliran Wahabi. Keduanya bersatu atas dasar satu kepentingan bersama. Istilah aliran Wahabi diambil dari nama Syeikh Muhamad bin Abdul Wahhab bin Sulayman at-Tamimi al-Najdi, dari klan Tamim, dilahirkan di Uyaynah (Huraimilah), Najd pada 1115-1206 H atau 1703-1791 M. Beliau telah menghafal al-Quran sejak usia 10 tahun dan mendalami fikih mazhab Hambali. Wilayah Nejed pertengahan abad ke-12 H nyaris hancur karena khurafat dan bidah mentradisi. Pada masa berkuasanya Pangeran Muhammad Su'ud (1139-1179 H) beliau diangkat sebagai guru dan orang terhormat. Dakwah Abdul Wahhab dijadikan standar gerakan dakwah di seluruh wilayah Arab Saudi hingga kini.

Pelaku anarkisme, seperti membunuh dengan dalih pesan agama, merasa paling benar dan pihak lain salah karena anggapannya membawa misi suci untuk menegakkan izzah Islam. Munculnya aliran sesat, terorisme, dan kemiskinan berpotensi merusak akidah dan akhlak umat, sehingga perlu penanganan serius dengan antisipasi oleh ulama dan umat untuk bertanggung jawab secara moral, ubudiyah, dan syariah. Citra Islam saat ini banyak disalahpahami, terutama karena dianggap lekat dengan kekerasan bahkan terorisme. Hanya umat Islam yang bisa memperbaiki citra negatif tersebut dengan menampilkan praktik kehidupan yang cinta perdamaian, bersahabat, dan prodemokrasi. Citra Islam di dunia memiliki wajah banyak. Di negara-negara Timur Tengah, Islam mempunyai fungsi politik tinggi. 


\section{QUALITY}

Volume 5, Nomor 1, 2017: 104-139

Sebuah partai, misalnya, kemungkinan memperoleh simpati publik jika menggunakan nama Islam. Kesan tentang Islam sangat bervariasi. Bisa jadi mengesankan citra positif, negatif, kekerasan atau bahkan sangat keras. Hal itu dipengaruhi oleh berbagai faktor, termasuk berbagai kesalahpahaman tentang Islam. Jika ingin memperbaiki citra itu, umat Islam sepatutnya bekerja keras. Jangan selalu bersikap reaktif dengan apa yang berlangsung di Barat dan menyederhanakan persoalan. Perlu dikembangkan komunikasi dengan bahasa internasional yang bisa menghubungkan secara baik antara Barat dan Timur. Islam dimengerti dari perilaku mayoritas penganut Islam sendiri. Tentang persoalan demokrasi, misalnya, Francois Burghat melihat, sebenarnya umat Islam bisa memperkuat tafsir ajaran Islam yang sesuai dengan prinsip-prinsip demokrasi. Mayoritas umat Islam bisa membuat ijmak atau kesepakatan pada tafsir yang lebih moderat dengan menekankan nilai-nilai kemanusiaan universal. Remy Madinier menilai, Islam di Indonesia tumbuh dengan warna berbeda dibandingkan dengan situasi di dunia lain, terutama di wilayah Timur Tengah. Di Indonesia, Islam berkembang bersama budaya lokal dan menjadi bagian dari sejarah pembentukan negara-bangsa. Ekspresinya sangat beragam, mulai liberalis hingga fundamentalis. Indonesia bisa menjadi sampel menarik bagi negara dengan penduduk Muslim yang berusaha menerapkan demokrasi. Muslim di Indonesia mau mendukung proses demokratisasi. Masyarakat muslim mengambil nilai-nilai universal dari Islam untuk diserap dalam konstitusi negara. Semua itu dipengaruhi berbagai hal, termasuk sekularisasi yang didorong kelompok Islam moderat seperti Nurcholish Madjid (almarhum).

Gerakan reformasi yang sekarang melanda negara-negara di kawasan Timur Tengah sebenarnya sudah berlangsung 10 tahun lalu di Indonesia. Reformasi di Indonesia memperlihatkan semangat kaum Muslim untuk menerapkan demokrasi, kesetaraan laki-laki dan perempuan, serta kebebasan. Di tengah ketidakpastian situasi di negeri ini, Islam juga menjadi referensi untuk mencari jalan keluar. Meskipun realitasnya, penduduk Indonesia yang mayoritas beragama Islam, menurut Wakil Ketua Perhimpunan Dokter Spesialis Kedokteran Jiwa Indonesia, dr. Nalini M.Agung 


\section{QUALITY}

Volume 5, Nomor 1, 2017: 104-139

$\mathrm{SpKj}$, kondisinya kini terdapat perubahan perilaku berupa lebih mudah marah, main hakim sendiri, dan mudah terpancing melakukan kekerasan sebagai indikator buruknya kondisi kesehatan mental masyarakat Indonesia. Didukung dengan rasa tidak aman, cemas, dan depresi akibat kemiskinan, kebodohan, ketidakadilan hukum, sosial, maupun ekonomi, dan ketidakpastian masa depan. Semua itu bersumber pada krisis multidimensi, frustasi, konflik, dan sikap saling mencurigai hingga menjadi paranoid. Hal ini menimbulkan peningkatan angka kriminalitas, kekerasan, kenakalan remaja, korupsi, dan hukum rimba (Kompas, 8 Juni 2011).

\section{Pendidikan dan Terorisme di Kudus}

Lembaga pendidikan agama dan keagamaan bertanggung jawab mencetak generasi yang berpikir tak sempit dalam memahami teks ajaran agama agar tidak menjadi pelaku teror. Oknum pelaku teroris (sebagian) pernah mengaji di pesantren. Jika pesantren tidak membentengi diri dengan perangkat dan stakeholdernya dikhawatirkan merusak kiprah pesantren yang jumlahnya besar hanya karena kerikil kecil. Perlunya fokus perihal strategi antisipasi dan tindakan pencegahan (preventif) terhadap munculnya embrio teroris yang mana sejak peristiwa Bom Bali pertama 2002, setidaknya 1.300 orang Indonesia dipidana akibat terorisme, 900 di antaranya telah menjalani masa hukuman dan kembali ke masyarakat. Kondisi ini, Diplomat Australia, Greg Ralph, bertanya pada pengasuh Pesantren Mahasiswa An-Nur, K.H Imam Ghazali Said pada Ahad, 5 Juni 2011. Greg menilai, selama ini pesantren dikenal di luar negeri sebagai lembaga tradisional yang mampu melahirkan santri toleran, tapi mengapa sekarang ada kadernya yang radikal? Imam Ghazali menjelaskan, radikalisme di Indonesia selalu memiliki keterkaitan dengan pesantren Ngruki dan cabang-cabangnya di seluruh Indonesia serta sejumlah pesantren yang membawa paham Wahabi yang radikal di Indonesia (Republika, 6 Juni 2011).

Dalam konteks kota Kudus, ada 90-an ponpes. Jumlah tersebut merupakan aset bangsa agar santri menjadi tokoh agama yang berpegang pada ajaran Nabi SAW yakni santun, tidak anarkis, sehingga perlu dibekali dengan pola pikir yang tidak beku. Hal yang harus dipahami bahwa menjadi teroris setelah menjadi alumni. Hal ini 


\section{QUALITY}

Volume 5, Nomor 1, 2017: 104-139

sangat dipengaruhi kondisi lingkungan yang sedang dihadapi di luar pesantren/sekolah. Dari 90-an ponpes tersebut, ada satu pesantren di Kudus yang alumninya menjadi teroris. Lembaga ini tahun 1937 didirikan oleh KH Abdul Mukhit, alumni Universitas Al-Azhar, Kairo, Mesir. Ketika Mukhit mengajar para santri dari berbagai pondok pesantren di Kudus, khususnya Kudus Kulon (sekitar Menara Kudus) kemudian digabungkan dalam satu wadah diberi nama Ma'ahid (berhimpunnya pondok) dengan sistem salaf (tradisional). Tahun 1957 Mukhit wafat digantikan K.Ahmad Zaini Ihsan dengan mengembangkan pendidikan umum. Lembaga ini satu alumninya (dari ribuan alumni) tergabung dalam jaringan teroris di Indonesia setelah lama lulus, dialah Bagus Budi Pranoto alias Urwah. Urwah lahir di Dukuh Klisat Rt.8/Rw.1, Desa Mijen, Kecamatan Kaliwungu, Kudus tanggal 2 November 1978. Ia pelaku bom Kedubes Australia tahun 2004 divonis 7 tahun penjara dan mendapat pembebasan setelah 4 tahun disel. Ia tertembak mati oleh Densus 88 Anti-teror Polri bersama Noordin M Top, Aris Sudarso alias Aji alias Suparjo Dwi Anggoro, dan Susilo alias Adib di Kampung Kepuhsari Rt.3/Rw.11, Kelurahan Mojosongo, Kecamatan Jebres, Solo tanggal 16 September 2009. Urwah alumni Madrasah Diniyah Muawanatul Muslimin Kauman Kudus, Madrasah Ibtidaiyah (MI) Ma'rifatul Ulum I, Mijen, Kaliwungu, Kudus tahun 1989. Ia melanjutkan jenjang SLTP dan nyantri di Ponpes Ma'ahid Kudus. Tahun 1991-1997 nyantri di Ponpes Al-Muttaqin, Desa Sowan Kidul, Kecamatan Kedung, Kabupaten Jepara selama 6 tahun. Tersangka bom Hotel JW Marriott dan Ritz Carlton 17 Juli 2003 (buronan bersama Syaifuddin Zuhri, M.Syahrir, dan Sudarso) dan menyembunyikan Azhari dan Noordin M.Top, divonis 3 tahun 6 bulan yang akhirnya dibebaskan. Pindah sejak Januari 2007 menjadi warga Dukuh Bantarejo Rt.1/IV, Desa Kadokan, Kecamatan Grogol, Kabupaten Sukoharjo setelah kawin dengan Rina Yuni Astuti, berprofesi sebagai da'i di masjid Al-Hikmah, Dukuh Buntarejo. Sebelumnya mengajar bahasa Arab tahun 1998 (selama setahun) di Ponpes Islam Nurul Huda Dukuh Kedung Jampang, Desa Karangreja, Kecamatan Kutasari, Purbalingga, Jawa Tengah. 


\section{QUALITY}

Volume 5, Nomor 1, 2017: 104-139

Perlunya dipahami bahwa mata rantai teroris dapat menyebar melalui jaringan almamater, kekerabatan, dan interaksi sosial, sehingga pesantren sebagai kawah candra dimuka pendidikan keagamaan perlu mengantisipasi diri dengan memahami sepak terjang embrio teroris. Di sisi lain, respon masyarakat Kudus terhadap pemakaman pelaku teroris, Urwah di Kudus, muncul pro (setuju) yang ditafsiri publik, teroris dibenarkan, melaksanakan pesan islami (jihad) dan kontra (tidak setuju) dipahami melanggar prinsip Islam karena sebagai pembunuh. Pro-kontra merupakan respon publik terhadap teroris, meskipun akhirnya warga menerima pemakaman karena adanya negosiasi berbagai pihak. Bagi yang menerima berdalih bagaimana pun dia pernah tinggal di Klisat, Mijen, Kudus.

Penerimaan difasilitasi Kades Mijen, Kaliwungu, Kudus (Rapat Muspika di Balai Desa Mijen pukul 14.45 s.d 17.00 WIB difasilitasi Kades Mijen, H.Sujono KS, dihadiri Camat Kaliwungu, Eko Dwi Djatmiko, Kapolsek Kaliwungu, Tugiyanto, Danramil Kaliwungu, Kapten.Inf. Harjono, Karangtaruna dan BPD Desa Mijen. Keluarga menandatangani surat pernyataan bermaterai yang memutuskan bahwa jenazah Urwah dapat dimakamkan di Desa Mijen bila (1) pihak keluarga menjamin keamanan kepada pihak yang kontra atau keamanan selama proses pemakaman, (2) pihak keluarga melarang pihak yang tidak berkepentingan langsung, seperti kelompok jamaah dari Solo untuk melayat, (3) tak memasang spanduk maupun karangan bunga yang bertuliskan pahlawan jihad atau tulisan lain yang memicu konflik, (4) pemakaman secara sederhana.

Adapun pihak yang menolak pemakaman dimotori Ketua Karangtaruna, Mbar Sidi, Ketua Badan Perwakilan Desa (BPD) Desa Mijen berdasarkan rapat anggota BPD di balai desa berjumlah 9 orang, 8 menolak dan satu abstain. Pihak pendemo menolak (akan menghadang) jika jenazah dimakamkan di desanya dengan alasan bukan lagi penduduk Klisat dan khawatir desa dicap sebagai sarang teroris. Penolakan juga dimotori oleh Sukis Jiwantomo, Forum Masyarakat Cinta Damai, Ketua MUI Kudus, H.Syafiq Nashan (almarhum). Pemerintah diharapkan mencarikan tempat pemakaman Urwah yang bebas konflik karena munculnya penolakan dan 


\section{QUALITY}

Volume 5, Nomor 1, 2017: 104-139

penerimaan. Jika masih ada keinginan yang bertolak belakang, pemerintah diminta turun tangan untuk mencari jalan keluar. Pro-kontra direspon oleh Plt. Ketua MUI Kota Solo, Zainal Abidin Adnan, kedua jenazah teroris, Hadi Sosilo (Adib) dan Urwah, keduanya berhak dimakamkan yang dipilih keluarganya, apalagi mereka muslim. Manusia yang sudah meninggal wajib dimakamkan, pihaknya mempertanyakan orang yang menolak pemakaman melanggar HAM (Jawa Pos, 26 September 2009).

Menurut anggota MUI Jateng, K.Tamam Qaolani, apapun statusnya, asalkan jenazah muslim berhak dimakamkan layaknya muslim dan sengketa pemakaman jenazah teroris menjadi kewenangan pemerintahan setempat. Solusinya, makam khusus teroris (Suara Merdeka, 23 Oktober 2010). Akhirnya, Urwah dimakamkan di Kudus dianggap asli warga Kudus. Hal ini menandaskan bahwa respon masyarakat santri, jika tidak diantisipasi menimbulkan pola pikir yang seakan-akan membenarkan bahwa teroris pun diterima masyarakat, maknanya teroris tidak selalu dianggap salah oleh masyarakat. Begitu pula, Zaenuri, 30 tahun ditembak mati oleh Densus 88 Rabu 8 Mei 2013 dan dimakamkan pada 24 Mei 2013 di Desa Klumpit, Rt.1/5 Kec Gebog, Kudus. Adapun Bayu Setianto alias Harun tewas ditembak Densus 88 di Dusun Kembaran, Desa Ungaran, Kecamatan Kutowinangun, dimakamkan di makam umum ploso Desa Hadipolo, Kecamatan Jekulo, Kudus Jumat 24 Mei 2013. Pemakaman Bayu Setianto dan Zainuri, kedua teroris ditembak Densus 88 di Kebumen pada 8 Mei 2013. Bayu warga Desa Hadipolo, Jekulo, Kudus semula ditolak pemakamannya di Hadipolo karena keluarga menyerahkan pemakaman pada Tim Pembela Muslim, warga menghendaki pemakaman oleh pihak desa. Pada 24 Mei 2013 jenazah dimakamkan di Hadipolo. Tak bedanya jenazah Zainuri warga Desa Klumpit Rt.1/5, Gebog, Kudus akhirnya dimakamkan di Klumpit pada 1 Juni 2013. Antara perjanjian prapemakaman dengan realitas tak sama karena yel-yel menganggap teroris laksana pahlawan menjadi pemandangan baru pemakaman di Kudus. Idealnya Kudus tak lagi menjadi sarang pemakaman teroris jika ingin nihil dari konflik. Embrio teroris dan jaringannya di Kudus diduga masih bercokol di berbagai daerah (sebagaimana data 


\section{QUALITY}

Volume 5, Nomor 1, 2017: 104-139

yang digali penulis) sehingga perlu kesigapan antarelemen masyarakat dan pemerintah. Keberadaan oknum teroris (diakui atau tidak) membawa nama buruk Kudus apalagi dijuluki kota santri.

\section{Mata Rantai Teroris}

Adanya data bahwa pelaku teroris merangkai melalui jalur keluarga karena dendam. Sebagaimana Farihin -pelaku pengeboman Kedutaan Besar Filipina- ayahnya pernah terlibat peristiwa pengeboman Cikini tahun akhir tahun 1950-an. Begitu pula saudara dari Farihin terlibat pengeboman di Atrium Senin, Jakarta dan adik Farihin terlibat pengeboman gereja di Poso. Al Gozi yang pernah melihat langsung bahwa bapaknya ditembak oleh aparat keamanan karena ikut dalam Komando Jihad. Pada 24 Oktober 2015 ada 30 WNI asal Jawa Tengah yang dideportasi pemerintahan Malaysia karena transit di Malaysia dan akan bergabung dengan ISIS di Suriah, 5 orang di antaranya warga Kudus. Sebelumnya, Densus 88 juga menyergap hidup-hidup Abu Thalut (menikahi warga Kudus) pada 10 Desember 2010 di Dukuh Pondok Rt.4/3, Desa Bae, Kecamatan Bae, Kudus. Kini telah bebas dan menyadari kesalahannya bahkan menjadi orang yang menolak keberadaan ISIS. Eka Zumi Astuti, mahasiswi PT di Semarang warga Kudus Rt 4/IV Desa Jati Kulon, Jati, Kudus (diduga) korban NII, pernah ditahan Mapolrestabes Semarang.

Dalam konteks lain, bila pemakaman teroris di Kudus mereda setelah berlalu, masyarakat Kudus menolak hal-hal yang berseberangan dengan Islam, seperti penggunaan tempat ibadah yang tak prosedural dan aliran sesat. Konflik antara warga Desa Getas Pejaten, Kec.Jati, Kudus karena pemanfaatan rumah toko (ruko) di gedung IPIEMS jl.Agus Salim dijadikan gereja pimpinan pendeta F. Iskandar Wibawa karena dianggap salah fungsi. Respon Bupati Kudus, menerbitkan surat Nomor 450/7777/11/2006 tanggal 23 November 2006 agar menghentikan ruko sebagai tempat ibadah, aparat Polres disiagakan (Radar Kudus, 27 November 2006).

Jamaah dzikrussholikhin pimpinan Nur Rokhim Rt.06/I1, Desa Golantepus, Kecamatan Mejobo, Kudus, mengaku bertemu malaikat akibat ketaatannya dzikir setiap malam. Suatu malam ditemui cahaya mengajak ruhnya bersinggah pada rumah 


\section{QUALITY}

Volume 5, Nomor 1, 2017: 104-139

mewah, cahaya dianggap malaikat. Sebagian warga menganggap aliran sesat, suasana desa memanas, aparat desa dan kepolisian mendamaikan kedua belah pihak di balai desa setempat (Radar Kudus, 4 dan 8 September 2007). Tetapi mengapa dalam hal pelaku teroris, mayoritas masyarakat Kudus pasif? Diduga karena, pertama, karakter masyarakat Kudus permisif, aksinya muncul jika ada lokomotif atau penggerak (sebagaimana dicontohkan peran Ketua Karangtaruna dan BPD Desa Mijen, Kaliwungu, Kudus). Kedua, lebih berorientasi pemenuhan kebutuhan hidup, sehingga terorisme dipandang sambil lalu. Ketiga, perlunya pendalaman kaitannya analisis faktor, mengapa pelaku teroris tidak mendapatkan perhatian ekstra, sebagaimana aliran sesat atau penggunaan tempat ibadah yang menyalahi prosedur? Hingga sekarang pun, embrio kecil penolakan teroris di Kota Kudus sirna di tengah dinamika. Keempat, ulama memiliki andil dalam mewarnai respon umat yakni antara pro dan kontra memandang pemakaman teroris tapi kurang mereaksi.

Diduga adanya indikasi bahwa para teroris berjejaring dengan Ponpes, di antaranya Ponpes Al-Mukmin, Ngruki, Sukoharjo, yang pernah dipimpin Ustad Abu Bakar Ba'asyir (kini disel di Nusakambangan) dicurigai sarang teroris. Dalam tubuh pesantren tersebut muncul dua kelompok orientasi, konservatif fundamentalis dan moderat (Fuaduddin dan Soemanto, 2007). Image tersebut menambah citra kelam dunia pesantren. Bukti riil menangkis image tersebut perlu memberi pemahaman secara utuh bagi komunitas pesantren tentang teroris dan faktor yang menimbulkan tumbuhnya teroris, agar tercipta generasi yang alim, agamis, berbudaya, dan berperadaban dengan cara 'didekati' dengan bijak, tidak hanya obyek kecurigaan. Pemahaman yang muncul bahwa teroris memiliki misi menentang negara karena kedzalimannya terhadap umat Islam dan ingin mengubah dasar negara. Meskipun embrio penentang Pancasila, ternyata bukan domain pesantren, tetapi merambah pada perguruan tinggi umum dan agama. Sebagaimana terdapat di wilayah Kabupaten Salatiga, Jateng dengan eksisnya NII meskipun taraf merayap (Jawa Pos, 28 Mei 2010). Jika hal ini tak diantisipasi, kekuatan teroris (di antaranya menegakkan syariat Islam) akan semakin kokoh. 
QUALITY

Volume 5, Nomor 1, 2017: 104-139

\section{Kendala Pemberantasan Teroris}

Radikalisme di manapun dan kapan pun selalu menjadi masalah dalam kehidupan suatu bangsa. Lebih-lebih ketika radikalisme berwujud aksi kekerasan yang merugikan kehidupan bersama seperti konflik fisik, teror atau terorisme, hingga perang terbuka. Apa pun alasan atau motifnya, termasuk atas dorongan keyakinan agama atau membela paham tertentu, radikalisme tetap bermasalah (Nashir, 2017:25). Dalam realitanya, tantangan pemberantasan teroris di Indonesia menurut Golose berupa (1) memerangi pola pikir radikal, (2) radikalisasi terjadi secara sistematis dan terorganisasi (pemikiran radikal di masyarakat, perekrutan anggota teroris, (3) kemampuan bermetamorfosa dengan organisasi teroris, seperti Majelis Mujahidin Indonesia (MMI), Laskar Jundullah, Komite Penanggulangan Krisis (KOMPAK), Fakta (Forum Anti Gerakan Pemurtadan) Palembang, (4) pemberantasan teroris menitikberatkan hukum pidana (yang lemah prakteknya, khususnya pemenjaraan), dan (5) kontroversi dalam masyarakat mengenai teroris dan gerakan radikal, dianggap pahlawan (syuhada, mujahid) satu sisi dan merusak kenyamanan sosial sisi lainnya (2009:35-58). Dengan demikian, peta telaah meliputi pertama, memformulasikan strategi antisipatif munculnya embrio teroris oleh komunitas pesantren. Strategi ini berpijak dari desain deradikalisasi yang dilakukan pemerintah. Kedua, bentuk aksi nyata melawan teroris dengan pendekatan interdisipliner. Menurut Golese (2009:109) dengan (a) pemahaman terhadap penyebab terjadinya radikalisme dan terorisme, (b) pendidikan yang rendah dan pengajaran yang dogmatis, (c) krisis identitas dan pencarian motivasi hidup, perekonomian yang kurang memadai, keterasingan secara sosial dan budaya, keterbatasan akses politik, solidaritas antara sesama umat yang tinggi, dualisme aspirasi masyarakat, pemahaman terorisme sebagai permasalahan perspektif agama, sosial budaya, sejarah dan politik, keamanan dan kestabilan negara, perspektif hubungan organisasi dan hubungan internasional, perspektif hukum, psikologi, komunikasi dan teknologi informasi, sinergi multipihak dalam pemberantasan teroris, peran cendikiawan dari berbagai ilmu, badan atau lembaga pemerintah, LSM, Ormas, media massa, pihak swasta, dan keluarga. 
QUALITY

Volume 5, Nomor 1, 2017: 104-139

\section{Mewujudkan Pendidikan Toleran sebagai Upaya Menangkal Radikalisme}

Sebagai ilustrasi, seorang perempuan Rochom P'ngieng hilang saat masih kanakkanak pada tahun 1989 ketika mengembalakan kerbau di belakang rumahnya di Distrik O'yadao, dekat hutan Kamboja. Jaraknya sekitar $600 \mathrm{~km}$ di sebelah timur laut Kota Phnom Penh, Provinsi Ratanakkiri, kawasan terpencil dan berbatasan langsung dengan hutan liar Kamboja. Tahun 2007, dia ditemukan ketika berusaha mencuri makanan warga petani dalam kondisi membungkuk seperti monyet, mengais-ngais tanah. Lantas ia dibawa pulang dalam kondisi telanjang. Perempuan yang berusia 29 tahun menghabiskan waktu 18 tahun hidupnya di hutan dan ditemukan berjarak sekitar $100 \mathrm{~m}$ dari rumahnya. Kemudian ia menghilang lagi dan ditemukan di sebuah jamban (toilet alami) di luar rumah sekitar $100 \mathrm{~m}$ dari rumahnya. Ia ditemukan seorang penduduk desa di dasar sebuah liang dalam, yang merupakan sumur yang tak dipakai lagi dan dijadikan sebuah jamban sedalam $10 \mathrm{~m}$. Tubuhnya terendam (11 hari) oleh tinja hingga setinggi dadanya. Orang Kamboja menjulukinya 'perempuan hutan' dan 'gadis setengah binatang'. Sejak bergabung kembali dengan masyarakat, dia berulang kali terkena penyakit setelah menolak makanan. Sebelum menghilang, Rochom belum bisa berbicara, kecuali beberapa kata. Namun ia mengerti jika diajak bicara oleh anggota keluarga (Kompas, 8 Juni 2010, hlm.10).

Gambaran riil tersebut menandaskan bahwa siapa pun yang berada dalam lingkungan dengan 'warna' tertentu besar peluangnya berperilaku sebagaimana tradisi di lingkungan tersebut. Begitu pula, bila seorang anak sejak kecil hingga dewasa berada di lingkungan yang tidka toleran, tentu akan menjadi pelaku intoleran karena perilaku itu dianggap hal wajar. Di sisi lain, terjadinya konflik intern dan antar-umat beragama di negeri ini diakibatkan oleh pemahaman yang sempit oleh sebagian umat beragama terhadap agamanya dan agama yang dipeluk pihak lain. Hal ini bila tidak disikapi dengan langkah bijak secara riil oleh berbagai elemen masyarakat dan pemerintah, maka konflik berkepanjangan antar dan intern-umat beragama menjadi penyakit akut. Dengan demikian, perlu upaya yang bersumber dari lingkungan keluarga dan lingkungan pendidikan. Pendidikan Islam yang toleran harus 


\section{QUALITY}

Volume 5, Nomor 1, 2017: 104-139

diwujudkan dengan cara, pertama, seringnya dialog antar-umat agama dengan bekal kesadaran tinggi. Hal ini sebagai modal awal untuk mewujudkan kehidupan toleran. Tentunya diawali dengan interaksi intensif, positif, dan akrab antar-umat beragama. Terdapat realitas yang menarik kaitannya dengan respon publik yang resisten terhadap Islam radikal. Masyarakat menilai, keberadaan kelompok radikal aktivitasnya mengakibatkan munculnya citra negatif terhadap agama dan umat Islam, bahkan sangat sedikit anggota masyarakat yang bersedia mendukung kelompok radikal. Dialog lintas agama jangan hanya berlangsung di tingkat elit dan bersifat retorika, tetapi dikembangkan hingga menjadi gerakan masyarakat awam dan menciptakan kerukunan dalam kehidupan nyata. Inti penting untuk mengurangi ketegangan atau konflik antarumat beragama. Wacana dialog lintas agama sudah didengungkan oleh pemerintah dan tokoh agama di Indonesia. Namun, selama itu, konflik dan kekerasan atas nama agama masih berlangsung karena dialog itu masih menjadi wacana elit. Data menandaskan bahwa konflik antar dan intern umat beragama menjadi 'tradisi' di negeri ini.

Kedua, meminimalisasi pemicu terjadinya konflik antar-umat beragama yang bersumber dari penggunaan atau pemanfaatan tempat ibadah yang 'over' karena mengganggu kenyamanan publik. Perlu diingat, data Kemenag Kudus, akhir tahun 2014 di Kudus terdapat 658 bangunan masjid, 22 gereja Kristen, 4 gereja Katolik, 11 wihara, 3 kelenteng, dan 1.928 musala. Adapun data tempat ibadah di Kudus tahun 2016 berdasarkan data dari Badan Musyawarah antargereja (Bamag) ada 40 gereja Kristen (sebelumnya 22 gereja), 1.928 musala, 658 masjid, 4 gereja Katolik, 11 wihara, 3 kelenteng. Dengan demikian, 'aksi' yang dilakukan oleh pelaku ibadah di tempat ibadah harus menghormati sesama dengan cara tidak menggunakan pengeras suara berlebihan. Kebutuhan sebagai sesama umat manusia meski berbeda agama diwujudkan dalam kehidupan nyata sehingga bila terdapat bintik-bintik konflik segera tertangani karena tercipta saling menyadari.

Ketiga, disepakati meskipun tak tertulis bahwa hal-hal yang didialogkan tidak berada pada wilayah teologi atau ajaran agama tetapi mendialogkan kebutuhan hidup 


\section{QUALITY}

Volume 5, Nomor 1, 2017: 104-139

yang berbasis kemanusiaan. Pesan ayat ini tidak untuk didialogkan. AlMaidah:17“'sesungguhnya telah kafirlah orang yang berkata: sesungguhnya Allah itu ialah Al-Masih putera Maryam”. Ayat 18 'orang Yahudi dan Nasrani mengatakan: Kami ini adalah anak-anak Allah dan kekasih-Nya. Kamu adalah bukan anak Allah dan bukan kekasih-Nya, tetapi manusia biasa". Dalam al-Maidah 72 "Sesungguhnya telah kafirlah orang yang berkata: Sesungguhnya Allah ialah Al Masih putera Maryam", padahal Al Masih (sendiri) berkata: "Hai Bani Israel, sembahlah Allah SWT Tuhanku dan Tuhanmu”. Sesungguhnya orang yang mempersekutukan (menduakan) sesuatu dengan Allah maka pasti Allah SWT mengharamkan kepadanya surga dan tempatnya ialah neraka, tidaklah ada bagi orang zalim seorang penolong. Al-Maidah 73 "Sesungguhnya kafirlah orang yang mengatakan bahwasanya Allah salah satu dari yang tiga, padahal sekali-kali tidak ada Tuhan (yang berhak disembah) selain Tuhan Yang Esa. Jika mereka tidak berhenti dari apa yang mereka katakan itu, pasti orang-orang yang kafir di antara mereka akan ditimpa siksaan yang pedih". AlMaidah 75 "Al Masih putera Maryam (Isa) hanyalah seorang rasul”.

Keempat, melaksanakan sembilan konsep pembelajaran demokratis; yakni menyertakan nilai demokrasi dalam proses pembelajaran berupa (1) pembelajaran yang memberikan perlindungan terhadap pelaku hukum, mewujudkan kebebasan berpendapat dan berorganisasi/berserikat, mengedepankan musyawarah mufakat dalam proses pembelajaran, memberikan pemahaman dengan cara tidak memaksakan kehendak pendidik, menghormati perbedaan pendapat dalam proses pembelajaran, selalu memberikan motivasi kepada peserta didik yang belum siap menerima materi ajar atau yang belum memahami materi ajar, memberikan kebebasan berekspresi dengan batasan tidak melanggar norma agama, norma hukum, norma sosial, dan norma akademik, (2) pendidikan menerapkan nilai humanis maksudnya adalah pendidikan yang memanusiakan manusia dengan cara memahami kekurangan dan kelebihan potensi yang dimiliki tiap individu, (3) mengaplikasikan ruh pendidikan yakni hubungan komunikatif antara peserta didik dengan pelaku pendidikan di saat (masih) aktif menjadi sivitas akademika ataupun telah lulus, (4) mengedepankan 


\section{QUALITY}

Volume 5, Nomor 1, 2017: 104-139

konsepsi pendidikan bermartabat yakni menghormati keberadaan peserta didik sebagai manusia yang berpotensi maju, berkembang, bahkan mundur dari sisi prestasi dan lainnya, (5) mengaktualisasikan pendidikan multikultural yakni pendidikan yang menghormati perbedaan suku, ras, dan kelompok, (6) pembelajaran yang tidak mendeskriditkan, mengerdilkan, dan tidak berprasangka buruk terhadap potensi perempuan (tidak bias jender), (7) mengaktualisasikan pendidikan yang pluralis yakni menghormati peserta didik dan pelaku/penyelenggara pendidikan meskipun berbeda agama dan keyakinan, (8) pendidikan yang tidak melakukan kekerasan, baik kekerasan secara fisik ataupun psikis yang dilakukan oleh pendidik kepada peserta didik, peserta didik terhadap pendidik, penyelenggara pendidikan terhadap peserta didik atau pendidik, sedangkan kekerasan fisik seperti menampar, mencubit, dsb., adapun kekerasan psikis seperti mendeskriditkan, mencemooh, dsb., dan (9) pendidikan yang mengedepankan nilai hak asasi manusia (HAM) meliputi hak-hak yang diturunkan Tuhan kepada hamba-Nya antara lain hak hidup, hak berpendapat, hak untuk pandai, hak beragama, dsb.

Bila dikaitkan dengan terorisme, radikalisme bukan proses yang instan dan sederhana, prosesnya kompleks dimulai dari pengenalan, identifikasi diri, indoktrinasi, radikalisasi hingga tindakan teror ( Agus SB, 2016:21). Dengan demikian, pendidikan berperan sebagai penangkal awal agar benih-benih terorisme teratasi dan terantisipasi. Pihak yang bertanggung jawab antara lain Kemenag dan Dikbud, tokoh agama, pendidik dan instansi pemerintah sipil/militer berkoordinasi antar-aparaturnya secara padu dalam bentuk forum komunikasi intensif, bukan saat terjadinya korban. Kenyamanan hidup warga merupakan kebutuhan primer sebagai tanggung jawab negara berpijak pada UU Nomor 7 Tahun 2012 tentang Penanganan Konflik Sosial. Pasal 10 Pemerintah dan Pemda membangun sistem peringatan dini mencegah konflik di daerah yang diidentifikasi berpotensi konflik; dan/atau perluasan konflik di daerah yang sedang konflik. Sistem peringatan dini berupa penyampaian informasi mengenai potensi konflik atau terjadinya konflik melalui media komunikasi. Pasal 11 membangun sistem peringatan dengan riset dan pemetaan 


\section{QUALITY}

Volume 5, Nomor 1, 2017: 104-139

wilayah potensi konflik secara cepat akurat; penyelenggaraan diklat; peningkatan dan pemanfaatan modal sosial; dan penguatan dan pemanfaatan fungsi intelijen. Dari aspek agama, berpijak pesan Nabi SAW terdapat 4 sendi stabilitas, ilmunya ulama/cendekiawan/intelektual, adilnya penguasa, dermanya si kaya, doanya fakir miskin. Bila salah satu sendi tak berfungsi yang terjadi instabilitas kehidupan. Ulama sebagai pewaris ilmu pendahulu bertugas mengajak publik menuju jalan kebajikan dan tanggalkan jalan kemunkaran dengan fatwa dan tulisannya. Dari aspek akademik, pemda perlu menggandeng akademisi untuk memetakan dan meriset keberadaan embrio teroris agar tertangani dan terdeteksi sedari dini. Semoga tak ada lagi teroris dan tak ada lagi pemakaman korban karena sebagai teroris di Kudus. Berdasarkan Konvensi PBB, hanya ada tiga isu kejahatan yang termasuk dalam indikator terorganisasi dan membutuhkan badan khusus yakni korupsi, narkoba, dan terorisme.

\section{Pendidikan Bela Negara seagai Alternatif Utama}

Kementerian Pertahanan RI merancang pelatihan bela negara untuk berbagai komponen bangsa dan ormas. Tujuannya adalah (1) menanamkan ideologi Pancasila dan menjaga keberagaman bangsa, (2) cinta Tanah Air, dan (3) menjaga dan pemahaman yang sama tentang Pancasila dan keberagaman bangsa. Program bela negara bernilai strategis dalam menghadapi spektrum ancaman perang modern yang memanfaatkan teknologi di era teknologi informatika perang bersifat amorf (tak berbentuk). Sebagaimana perang ekonomi diwarnai dengan pertarungan nilai. Bela Negara bukanlah militerisasi. Sistem pertahanan negara adalah integrasi antarkomponen bangsa, bukan berarti sama-sama mengangkat senjata. Batas antara bela negara dengan militerisasi tertuang dalam UU Nomor 3 Tahun 2002 tentang Pertahanan Negara pada penjelasan Pasal 9 bahwa upaya bela Negara adalah sikap dan perilaku warga Negara yang dijiwai oleh kecintaannya kepada NKRI yang berdasarkan Pancasila dan UUD 1945 dalam menjamin kelangsungan hidup bangsa dan Negara. Bela Negara tak ada kaitannya dengan latihan memegang senjata atau militerisasi/latihan militer. Bela Negara adalah hak warga negara untuk membina kesadaran berbangsa, bukan untuk kombatan, dan negara memfasilitasinya untuk bela 


\section{QUALITY}

Volume 5, Nomor 1, 2017: 104-139

negara. Bentuk bela negara berbeda antara berbagai elemen masyarakat. Bela Negara bila hanya dilaksanakan oleh militer sehingga memunculkan ketidakpercayaan sipil pada militer. Militer pun tak percaya atas kemampuan sipil melaksanakan pertahanan negara. Hak tiap warga Negara untuk terlibat dalam upaya bela negara diatur dalam UUD 1945 Pasal 27, 30, dan Pasal 31. Program Bela Negara harapannya bila ada kebutuhan darurat terhadap ancaman pertahanan Negara, para kader bisa dikerahkan. Arah yang diharapkan dengan Bela Negara di antaranya menyikapi perkembangan munculnya populisme, yakni paham anti-kemapanan yang cenderung menutup diri dengan karakter nasionalisme sempit. Populisme di antara cirinya adalah xenophobia, anti-asing, dan irasional. Ide dasar populisme adalah tak percaya kepada elite atau lembaga Negara.

Isu sentral dunia kini, yakni nasionalisme atau proteksionisme, korporatisasi perusahaan dan negara. Populisme bagian dari gerakan mundur di era globalisasi yang sempit dalam memandang arah kehidupan, seperti chauvinisme, nativisme, dan keagamaan yang sempit sehingga antikemajemukan. Populisme timbul akibat neoliberalisme yang direspon akibat kesenjangan yang ditimbulkan oleh kapitalisme. Empat pilar demokrasi, yakni media massa yang bebas dan tak memihak, masyarakat sipil yang kuat, parpol yang benar, dan penegakan hukum. Keberhasilan pendidikan bela negara diharapkan tak terjadi pelanggaran hukum atas perundang-undangan karena ketidaktahuan pelaku. Sebagaimana dialami FN (20 tahun) yang membawa bendera Merah Putih dengan coretan dan gambar dua pedang disilang berwarna hitam. Hal ini saat FN berunjuk rasa di depan Markas Besar Polri di Jalan Trunojoyo Jakarta Selatan Senin, 16 Januari 2017. FN ikut dalam unjuk rasa yang digelar Front Pembela Islam (FPI) untuk menuntut pencopotan Kapolda Jabar dan Mentro Jaya. Hal ini melanggar Pasal 68 UU Nomor 24 Tahun 2009 tentang Lambang Negara yang berbunyi "setiap orang yang mencoret, menulisi, menggambari, atau membuat rusak lambang negara dengan maksud menodai, menghina, atau merendahkan kehormatan lambang negara dipidana dengan pidana penjara paling lama 5 tahun atau denda paling banyak Rp 500 juta. 
QUALITY

Volume 5, Nomor 1, 2017: 104-139

\section{Simpulan}

Nalar pikir radikal dalam konteks agama sangat membahayakan kehidupan berbangsa di mana pun dan kapan pun. Lembaga pendidikan memiliki peran besar dalam menetralisasi agar nalar radikal tidak liar. Akan tetapi, didatarkan menjadi generasi yang toleran dan santun, menaati aturan negara dan agama dengan benar dan utuh. Realitanya, gerakan radikalisme dan terorisme selalu tumbuh tanpa henti. Kondisi ini memerlukan upaya riil dan tepat dari dunia pendidikan yang mencetak generasi anak bangsa. Upaya dapat dilakukan dengan mewujudkan pendidikan toleran, terutama melaksanakan sembilan konsep pembelajaran demokratis. Hal yang utama pula yakni mewujudkan konsep pendidikan bela negara yang dicanangkan oleh Kementerian Pertahanan RI era Presiden Jokowi dan Jusuf Kalla. Realisasi program bela negara di tengah masyarakat dan di dunia pendidikan formal dan formal perlu realisasi. Harapannya, kesenjangan antara harapan pemerintah agar warga negara mencintai negaranya (nasionalis) benar-benar terwujud. Tingginya kecintaan warga negara terhadap negaranya merupakan benteng utama menangkal terorisme.

\section{Daftar Pustaka}

Bakti, Agus Surya. (2016). Deradikalisasi Dunia Maya Mencegah Simbiosis Terorisme dan Media. Daulat Pess: Jakarta.

Bakti, Andi Faisal. (2016). Tangkal Radikalisme Kaum Intelektual. Kompas, Rabu 23 Maret.

Fuaduddin dan Soemanto. (2007). Melacak Nalar Radikalisme Kasus Pesantren AlMukmin Ngruki. Puslitbang Pendidikan Agama dan Keagamaan, Depag RI: Jakarta.

Golose, Petrus Reinhard. (2009). Deradikalisasi Terorisme Humanis, Soul Approach, dan Menyentuh Akar Rumput. Yayasan Pengembangan Kajian Ilmu Kepolisian: Jakarta.

Kristianawati, Ari. (2017). Deradikalisasi dari Sekolah. Kompas, Sabtu 17 Juni.

Maarif, Ahmad Syafii. (2017). Mencari Akar Ekstremisme-Terorisme dalam Pengantar Buku Reformulasi Ajaran Islam Jihad, Khilafah, dan Terorisme. Azyumardi Azra, dkk. Mizan: Bandung. 


\section{QUALITY}

Volume 5, Nomor 1, 2017: 104-139

Nashir, Haedar. (2017). Moderasi sebagai Jalan Ketiga dalam Pengantar Buku Reformulasi Ajaran Islam Jihad, Khilafah, dan Terorisme. Azyumardi Azra, dkk. Mizan: Bandung.

Sirry, Mun'im. (2016). Eksklusivisme Agama dan Pluralisme Politik. Kompas, Sabtu 4 Juni. 